\title{
Penapisan Derau Gaussian, Speckle dan Salt\&Pepper Pada Citra Warna
}

\author{
I. Purwanti Ningrum, A. Eko Putra dan D. Nursantika
}

\begin{abstract}
Quality of digital image can decrease becouse some noises. Noise can come from lower quality of image recorder, disturb when transmission data process and weather. Noise filtering can make image better becouse will filtering that noise from the image and can improve quality of digital image.

This research have aim to improve color image quality with filtering noise. Noise (Gaussian, Speckle, Salt\&Pepper) will apply to original image, noise from image will filtering use Bilateral Filter method, Median Filter method and Average Filter method so can improve color image quality. To know how well this research do, we use PSNR (Peak Signal to Noise Ratio) criteria with compared original image and filtering image (image after using noise and filtering noise).

This research result with noise filtering Gaussian (variance $=0.5$ ), highest PSNR value found in the Bilateral Filter method is 27.69. Noise filtering Speckle (variance $=0.5$ ), highest PSNR value found in the Average Filter method is 34.12. Noise filtering Salt\&Pepper (variance $=0.5$ ), highest PSNR value found in the Median Filter method is 31.27.
\end{abstract}

Keywords- Bilateral Filter, image restoration, derau Gaussian, Speckle dan Salt\&Pepper

\section{Pendahuluan}

Citra dalam visualisasinya sering kali mengalami penurunan kualitas yang dapat berupa rentang kontras benda yang terlalu sempit atau terlalu lebar, distorsi geometri (geometric distortion), kekaburan (blur), blur akibat obyek citra yang bergerak (motion blur), derau (noise) atau gangguan yang disebabkan interferensi peralatan akuisisi citra, baik itu berupa tranduser, peralatan elektronik ataupun peralatan optik.

Ika Purwanti Ningrum, Jurusan Teknik Informatika, Fakultas Teknik, Universitas Haluoleo, Kendari,email :ika.purwanti.n@gmail.com

Agfianto Eko Putro, FMIPA, Universitas Gadjah Mada, Yogyakarta

Dian Nursantika, Jurusan Teknik Informatika, Fakultas Sains dan Teknologi, UIN Sunan Gunung Djati, Bandung(e-mail: dianursantika@gmail.com)
Adanya derau pada sebuah citra dapat disebabkan kualitas yang rendah pada alat perekam citra, gangguan pada saat transmisi data, maupun keadaan lingkungan yang kurang baik (misal: cuaca). Penurunan kualitas ini mengakibatkan citra menjadi sulit diinterpretasi karena informasi yang disampaikan menjadi berkurang. Oleh karena itu, dibutuhkan suatu metode penapis derau pada citra guna mengembalikan kualitas citra agar menjadi lebih baik seperti sebelum terdegradasi oleh derau sehingga mudah diinterpretasi oleh manusia maupun mesin.

Penelitian-penelitian untuk meningkatkan dan memperbaiki kualitas citra sudah banyak dilakukan, mulai dari citra hitam-putih sampai dengan citra berwarna (color image). Metodemetode yang telah dihasilkan dari berbagai penelitian untuk menapis derau pada citra pun sudah mengalami banyak kemajuan. Salah satu metode tapis citra adalah Bilateral Filter. Bilateral Filter merupakan salah satu metode penapis citra yang mengkombinasikan kedekatan geometris dan kesamaan fotometrik (intensitas) antar piksel pada citra sehingga menghasilkan suatu citra yang lebih halus dengan tepian objek dalam citra tetap terjaga. Metode ini dapat memberikan hasil perbaikan yang lebih baik daripada metode-metode penapis yang telah ada sebelumnya karena keefektifannya dalam menapis derau dengan tetap mempertahankan tepian objek.

Perbaikan kualitas citra yang akan dibahas dalam penelitian ini adalah perbaikan kualitas citra warna yang sengaja dikenakan derau Gaussian, Salt\&Pepper dan Speckle, menggunakan metode Bilateral Filter. Penelitian ini juga melakukan penapisan derau menggunakan metode Median Filter dan Average Filter sebagai bahan perbandingan. Gambaran umum sistem penapisan derau pada penelitian ini ditunjukkan pada Gambar 1.

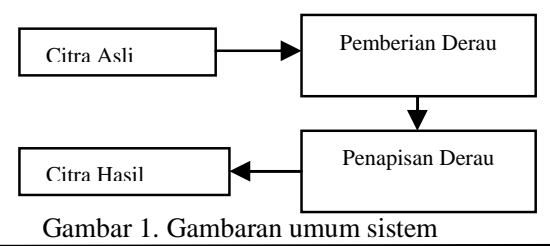




\section{Metode Penelitian}

\subsection{Pengolahan Citra Digital}

Citra didefinisikan sebagai fungsi dua dimensi $f(x, y)$ dimana $x$ dan $y$ adalah koordinat ruang dan besaran $f$ adalah intensitas dari citra tersebut pada koordinat $(x, y)$ [4]. Citra yang dilihat sehari-hari merupakan cahaya yang direfleksikan sebuah objek. Fungsi $f(x, y)$ dapat dilihat sebagai fungsi dengan dua unsur, pertama merupakan besarnya sumber cahaya yang melingkupi pandangan terhadap objek (illumination), kedua merupakan besaran cahaya yang direfleksikan oleh objek dalam pandangan (reflectance component). Keduanya dituliskan dengan fungsi yang berturut-turut $i(x, y)$ dan $r(x, y)$. Fungsi $i(x, y)$ dan $r(x, y)$ merupakan kombinasi perkalian untuk membentuk fungsi $f(x, y)$ yang dapat dituliskan dengan persamaan (1) [4].

$$
f(x, y)=i(x, y) r(x, y)
$$

dengan $0<i(x, y)<\sim$ dan $0<r(x, y)<1$.

\subsection{Derau (Noise)}

Kualitas citra sangat dipengaruhi oleh tingkat keberadaan derau. Citra warna dikorupsi oleh derau (noise) pada saat akuisisi citra atau selama transmisi citra [4]. Kualitas citra yang menurun saat akuisisi disebabkan oleh kondisi lingkungan yang kurang mendukung dan kualitas elemen sensor alat yang buruk. Penurunan kualitas citra pada saat proses transmisi dapat disebabkan oleh gangguan gelombang elektromagnetik selama proses transmisi data citra tersebut [4].

\subsubsection{Derau Gaussian}

Derau Gaussian berasal dari fungsi distribusi normal Gaussian dengan menggunakan peubah acak [4].

$$
p(z)=\frac{1}{\sqrt{2 \pi \sigma}} e^{-(z-\mu)^{2} / 2 \sigma^{2}}
$$

Pada persamaan diatas, variabel $z$ menunjukan grey level, $\mu$ adalah rata-rata dari nilai rata-rata $z$ dan $\sigma$ adalah standar deviasi. Derau Gaussian disebut juga Gaussian White Noise [4]. Disebut white noise karena pada saat nilai rata-rata dan standar deviasinya besar maka citra seolah-olah hanya terlihat seperti citra putih saja.

\subsubsection{Derau Speckle}

Derau Speckle adalah contoh derau yang bersifat multiplikatif. Penyebab utamanya adalah gangguan acak pada saat pengembalian citra.
Derau ini didefenisikan dengan persamaan (3) [4].

$$
p(z)= \begin{cases}\frac{1}{b-a} & \text { jika } a \leq z \leq b \\ 0 & \text { sebaliknya. }\end{cases}
$$

Dengan nilai rata-rata dari fungsi kepadatan derau:

$$
\mu=\frac{a+b}{2}
$$

dan nilai variance:

$$
\sigma^{2}=\frac{(b-a)^{2}}{12}
$$

dimana $\mu$ terdistribusi random dengan nilai ratarata $=0$ dan variance adalah konstanta non negatif yang besarnya dapat berubah-ubah. Semakin besar nilai variance, maka citra akan semakin kabur.

\subsubsection{Derau Salt\&Pepper}

Derau Salt \& Pepper adalah contoh derau yang bersifat impulsif (bipolar) [4].

$$
p(z)= \begin{cases}P a & \text { untuk } z=a \\ P b & \text { untuk } z=b \\ 0 & \text { sebaliknya }\end{cases}
$$

Pada persamaan (6), jika nilai $b>a$, maka grey level $b$ akan tampak sebagai sebuah titik terang dalam citra. Sebaliknya, level a akan tampak sebagai titik gelap, sehingga menghasilkan derau yang sangat kontras pada citra. Pada citra 8 bit misalnya, jika $a$ bernilai 0 , maka $b$ bernilai 255. Jika salah satu nilai $P a$ atau $P b=0$, impuls derau disebut unipolar. Jika nilai $P a$ atau $P b \neq 0$ dan utamanya jika $P a=P b$, nilai impuls derau akan menyerupai butir Salt \& Pepper yang tersebar acak diatas citra.

\subsection{Bilateral Filter}

Bilateral Filter merupakan salah satu metode restorasi citra khususnya penapis derau pada citra digital. Pada metode ini, nilai piksel citra hasil diperoleh dari rata-rata pembobotan piksel-piksel tetangga melalui proses konvolusi [2]. Bilateral Filter menggabungkan derajat keabuan berdasarkan kedekatan geometri dan kesamaan fotometrik. Kedekatan geometris (spasial) merupakan jarak antar piksel pada citra (jarak Euclidean). Sedangkan, kesamaan fotometrik merupakan kesamaan intensitas antara dua piksel pada citra [6].

Semakin kecil bobot spasial suatu piksel berarti semakin besar jarak piksel tersebut 
terhadap piksel yang sedang menjadi pusat analisis pada citra $g$, begitupun sebaliknya. Semakin besar perbedaan intensitas antara dua piksel, maka semakin kecil pula bobot fotometriknya, sehingga kontribusinya pada pembobotan pun kecil, begitupun sebaliknya [5]. Kedua bobot ini merupakan ciri khas metode Bilateral Filter.

Metode Bilateral Filter dikendalikan oleh 3 parameter, yaitu:

a. $\mathrm{N}=$ dimensi kernel.

b. $\sigma_{S}=$ standar deviasi untuk mengontrol faktor pembobotan spasial.

c. $\sigma_{R}=$ standar deviasi untuk mengontrol faktor pembobotan fotometrik.

Pembobotan spasial pada Bilateral Filter artinya pemberian bobot pada piksel sesuai dengan besarnya jarak antara piksel tersebut dengan piksel yang sedang menjadi pusat analisis pada citra $g$. Bobot spasial $\left(W_{S}\right)$ merupakan realisasi pengukuran kedekatan spasial dalam fungsi Gaussian yang mengukur jarak spasial antar piksel dengan menggunakan jarak Euclidean. Menurut [2], perhitungan bobot spasial pada tiap piksel ditunjukkan pada persamaan (7).

$$
\begin{aligned}
W S[x, u] & =\exp \left\{-\frac{\left.d^{2}[x],[x-u]\right\}}{2 \sigma^{2} s}\right\} \\
& =\exp \left\{-\frac{u^{2}}{2 \sigma^{2} s}\right\}
\end{aligned}
$$

a. $W_{S}[x, u]$ adalah bobot spasial tiap piksel pada kernel.

b. $x$ merupakan titik tengah kernel $(w(0,0))$

c. $u$ merupakan elemen-elemen tetangga pada kernel

d. $\sigma_{\mathrm{S}}$ merupakan standar deviasi untuk pembobotan spasial, yang besarnya dapat berubah-ubah, sesuai input dari user.

Sedangkan pembobotan fotometrik artinya pemberian bobot pada piksel sesuai dengan besar kecilnya perbedaan intensitas piksel tersebut dengan intensitas pada piksel yang sedang menjadi pusat analisis pada citra $g$. Bobot fotometrik $\left(W_{R}\right)$ merupakan realisasi pengukuran perbedaan intensitas pada kesamaan fotometrik dalam fungsi Gaussian, yang mengukur perbedaan intensitas antar piksel dengan menggunakan jarak Euclidean. Menurut [2], perhitungan bobot fotometrik pada tiap piksel ditunjukkan pada persamaan (8).

$$
\begin{aligned}
W_{R}[x, u] & =\exp \left\{-\frac{d^{2}\{g[x], g[x-u]\}}{2 \sigma^{2} R}\right\} \\
& =\exp \left\{-\frac{\{g[x]-g[x-u]\}^{2}}{2 \sigma^{2}}\right\}
\end{aligned}
$$

dengan:

a. $W_{R}[x, u]$ adalah bobot fotometrik tiap piksel pada kernel.

b. $x$ merupakan titik tengah kernel tersebut $(w(0,0))$.

c. $u$ merupakan elemen-elemen tetangga pada kernel

d. $g[x]$ adalah piksel yang menjadi pusat analisis pada citra terdegradasi.

e. $g[x-u]$ adalah piksel tetangga dari piksel $g[x]$.

f. $\sigma_{\mathrm{R}}$ merupakan standar deviasi untuk pembobotan fotometrik, yang besarnya tergantung input dari user.

Kedua bobot tersebut (bobot spasial dan bobot fotometrik) dinormalisasi menjadi satu nilai bobot $(W)$ seperti pada persamaan (9).

$$
W[x, u]=W_{S}[x, u] * W_{R}[x, u]
$$

Dalam penelitian ini digunakan 2 parameter, yaitu $\sigma_{S}$ dan $\sigma_{R} . \sigma_{S}$ merupakan standar deviasi untuk mengontrol faktor pembobotan pada $W_{S}$ (bobot spasial). $\sigma_{S}$ mempengaruhi besarnya dimensi kernel (A x A), karena $\sigma_{S}$ mengontrol kedekatan spasial dan kernel merupakan ukuran untuk menentukan besarnya jarak spasial. Semakin besar $\sigma_{S}$, maka objek pada citra semakin pudar. Namun bila $\sigma_{S}$ terlalu kecil maka penapisan terhadap derau tidak akan berdampak terlalu besar. Sedangkan $\sigma_{R}$ merupakan standar deviasi untuk mengontrol faktor pembobotan pada $W_{R}$ (bobot fotometrik). Semakin besar $\sigma_{R}$, maka derau pada citra semakin pudar, karena $\sigma_{R}$ mengontrol kekuatan penapisan derau pada citra yang terdegradasi.

Setelah pembobotan terhadap piksel-piksel dilakukan, maka nilai piksel hasil dapat dicari dengan persamaan (10) [1].

$$
\hat{f}[x]=\frac{\sum_{u=-N}^{N} W[x, u] g[x-u]}{\sum_{u=-N}^{N} W[x, u]}
$$

dengan:

a. $N=$ dimensi kernel.

b. $W[x, u]$ merupakan nilai bobot tetangga pada matriks bobot $W$. 
c. $g[x, u]$ merupakan piksel tetangga dari piksel $g[x]$.

d. $\hat{f}(x)$ merupakan nilai piksel hasil.

Gambar 2 menunjukkan relasi perhitungan bobot spasial dan bobot fotometrik metode Bilateral Filter.

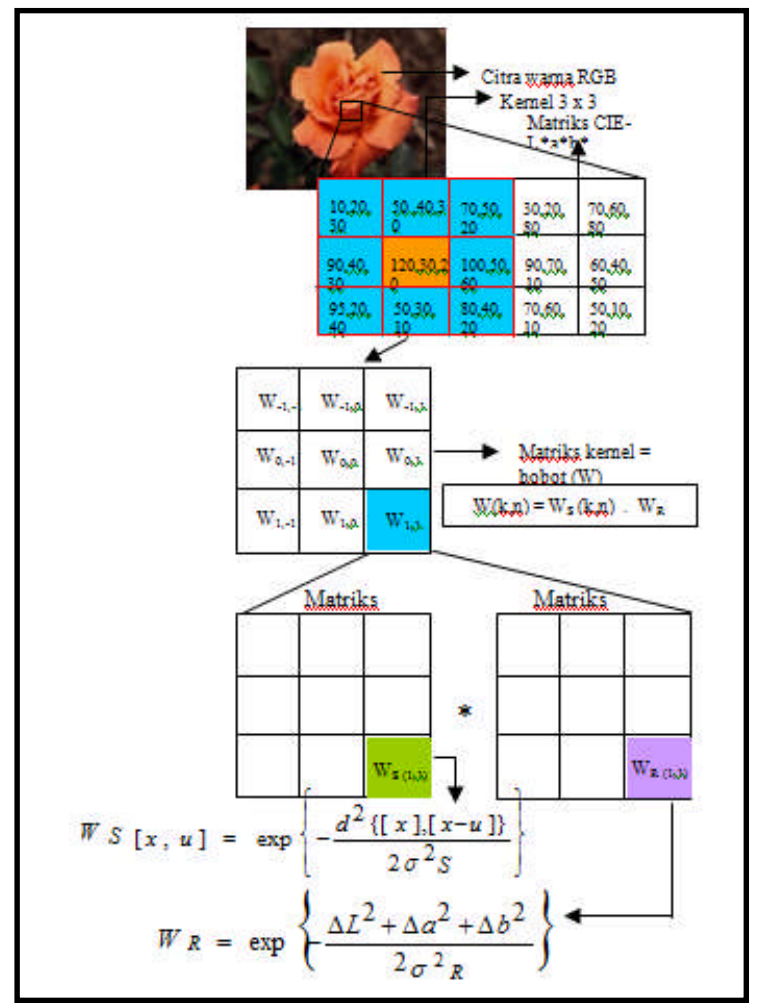

Gambar 2. Realisasi perhitungan bobot spasial dan fotometrik

Dalam penelitian ini, pengujian dengan metode Bilateral Filter akan dilakukan sebanyak 9 kali, dengan kombinasi 3 nilai parameter $\sigma_{S}$ dan $\sigma_{R}$ yang berbeda. Pemberian nilai parameter $\sigma_{S}$ dan $\sigma_{R}$ yang berbeda bertujuan untuk melihat pengaruh dari parameter-parameter tersebut terhadap kualitas citra. Nilai parameter $\sigma_{S}$ dan $\sigma_{R}$ dikategorikan menjadi tiga, yaitu : kecil, sedang, dan besar, seperti disajikan dalam Tabel 1.

Tabel 1. Nilai Parameter Pengujian $\sigma_{S}$ dan $\sigma_{R}$

\begin{tabular}{|c|c|c|c|}
\cline { 3 - 4 } \multicolumn{2}{c|}{} & \multicolumn{2}{c|}{ Standar Deviasi } \\
\cline { 3 - 4 } \multicolumn{2}{c|}{} & $\sigma_{s}$ & $\sigma_{\boldsymbol{R}}$ \\
\hline \multirow{3}{*}{ Kategori } & Kecil & 0,5 & 0,05 \\
\cline { 2 - 4 } & Sedang & 2 & 0,5 \\
\cline { 2 - 4 } & Besar & 20 & 5 \\
\hline
\end{tabular}

\subsection{Peak Signal to Noise Ratio(PSNR)}

Peak Signal to Noise Ratio (PSNR) merupakan suatu kriteria yang dapat digunakan untuk mengukur tingkat keberhasilan penapisan derau. PSNR mengukur skala logaritma antara citra asli dengan citra hasil penapisan. PSNR mengukur kesamaan antara citra asli dengan citra hasil penapisan dengan mengukur perbedaan piksel antara kedua citra tersebut. Range nilai PSNR sama dengan tak hingga untuk dua citra yang identik, sampai 0 untuk citra yang tidak mempunyai penggunaan komponen yang sama. Semakin besar nilai PSNR maka semakin baik penapisan derau yang dihasilkan. Penghitungan nilai PSNR dapat dilakukan dengan menggunakan persamaan (11).

$$
P S N R=20 \log \frac{\text { Peakvalue }}{\sqrt{\frac{1}{M N} \sum_{y=1}^{N} \sum_{x=1}^{M}(\hat{f}(x, y)-f(x, y))^{2}}}
$$

dengan:

a. $f(x, y)=$ matriks citra awal.

b. $\hat{f}(x, y)=$ matriks citra hasil.

c. $\mathrm{M}, \mathrm{N}=$ dimensi matriks citra.

d. Peak Value adalah nilai maksimum intensitas warna (misal : 255 untuk citra 8 bit).

\section{HASIL DAN PEMBAHASAN}

Adanya derau pada citra mengakibatkan citra menjadi sulit diinterpretasi karena informasi yang disampaikan menjadi berkurang. Penelitian ini bertujuan untuk memperbaiki kualitas citra warna yang terdegradasi derau Gaussian, Salt\&Pepper dan Speckle sehingga dapat mengembalikan kualitas citra tersebut menggunakan metode Bilateral Filter. Penelitian ini juga melakukan penapisan derau Gaussian, Salt\&Pepper dan Speckle menggunakan metode Median Filter dan Average Filter sebagai bahan perbandingan. Citra digital yang digunakan dalam penelitian ini adalah citra warna 24 bit dengan format BMP. Tool yang digunakan dalam penelitian ini menggunakan Matlab 7.5.

\subsection{Penapisan Derau Gaussian (variance = 0,01), Speckle (variance $=0,04$ ) dan Salt\&Pepper (variance $=0,05$ ) \\ a. Hasil penapisan derau Gaussian (variance = 0,01) dapat dilihat pada Tabel 2.}


Tabel 2. Nilai PSNR Metode Bilateral Filter, Median Filter, dan Average Filter dari Citra yang Terdegradasi Derau Gaussian (variance $=0,01)$

\begin{tabular}{|c|c|c|c|c|}
\hline \multicolumn{4}{|c|}{ Bilateral Filter } & \\
\hline$\sigma_{R}$ & 0,05 & 0,5 & 5 & $\begin{array}{c}\text { Rata-rata } \\
\text { tiap } \mathrm{s}_{\mathrm{S}}\end{array}$ \\
\hline 0,5 & 34,53 & 36,09 & 36,17 & 35,60 \\
\hline 2 & 34,82 & 37,82 & 37,70 & 36,78 \\
\hline 20 & 35,12 & 35,24 & 34,54 & 34,97 \\
\hline Rata-rata $\sigma_{R}$ & 34,82 & 36,38 & 36,14 & \\
\hline \multicolumn{4}{|c|}{ Median Filter : 37,62} & \\
\hline \multicolumn{4}{|c|}{ Average Filter : 37,76} & \\
\hline
\end{tabular}

Berdasarkan Tabel 2, nilai PSNR tertinggi terdapat pada metode Bilateral Filter pada kategori parameter sedang $\left(\sigma_{S}=2\right.$ dan $\left.\sigma_{R}=0,5\right)$ yaitu sebesar 37,82. Sedangkan untuk Median Filter nilai PSNR sebesar 37,62 dan Average Filter sebesar 37,76.

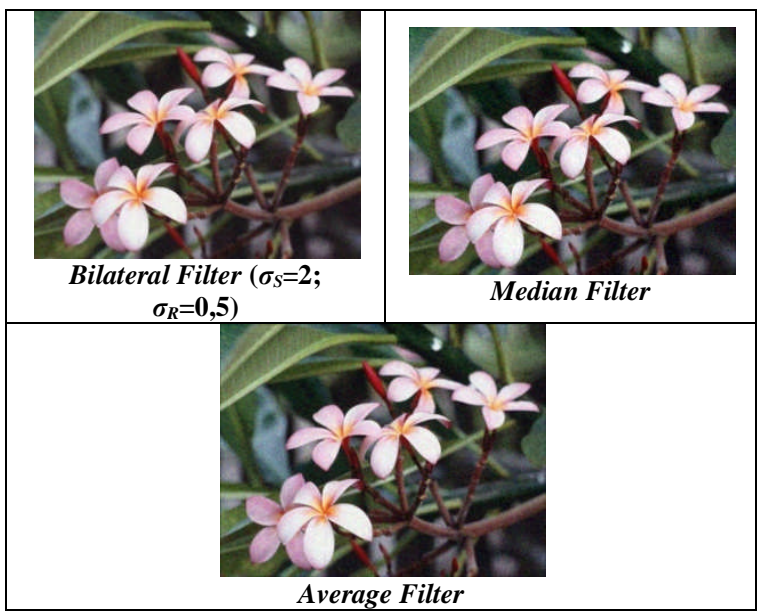

Gambar 3. Hasil penapisan derau Gaussian (variance $=0,01$ )

b. Hasil penapisan derau Speckle (variance $=$ 0,04) dapat dilihat pada Tabel 3.

Tabel 3. Nilai PSNR Metode Bilateral Filter, Median Filter, dan Average Filter dari Citra yang Terdegradasi Derau Speckle (variance $=0,04)$

\begin{tabular}{|c|c|c|c|c|}
\hline \multicolumn{4}{|c|}{ Bilateral Filter } & \multirow[b]{2}{*}{$\begin{array}{c}\text { Rata-rata } \\
\text { tiap } \sigma_{S}\end{array}$} \\
\hline$\sigma_{R}$ & 0,05 & 0,5 & 5 & \\
\hline 0,5 & 34,98 & 36,60 & 36,75 & 36,11 \\
\hline 2 & 35,10 & 38,24 & 38,14 & 37,16 \\
\hline 20 & 35,14 & 35,44 & 34,73 & 35,10 \\
\hline Rata-rata $\sigma_{R}$ & 35,07 & 36,76 & 36,54 & \\
\hline \multicolumn{4}{|c|}{ Median Filter $: 37,05$} & \\
\hline \multicolumn{4}{|c|}{ Average Filter : 37,98} & \\
\hline
\end{tabular}

Berdasarkan Table 3, nilai PSNR tertinggi terdapat pada metode Bilateral Filter pada kategori parameter sedang $\left(\sigma_{S}=2\right.$ dan $\left.\sigma_{R}=0,5\right)$ yaitu sebesar 38,24. Sedangkan untuk Median Filter nilai PSNR sebesar 37,05 dan Average Filter sebesar 37,98.

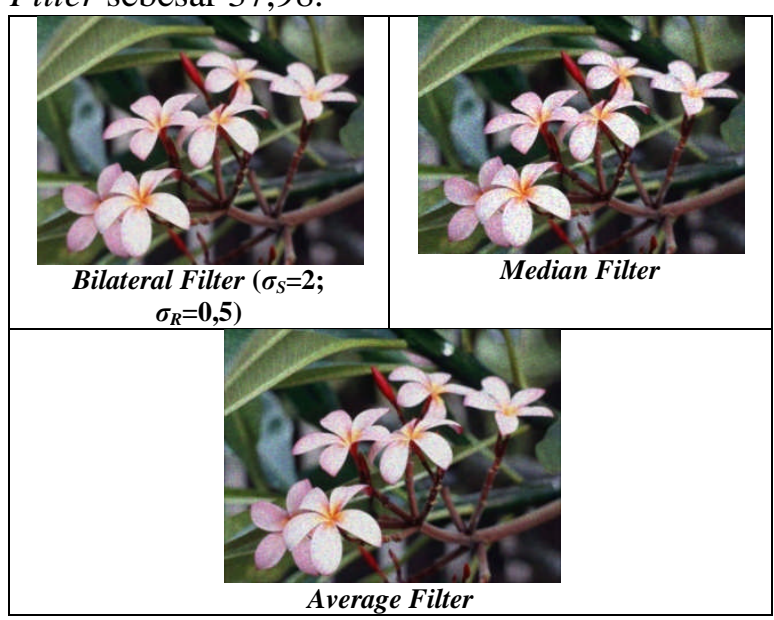

Gambar 4. Hasil penapisan derau Speckle (variance $=0,04)$

c. Hasil penapisan derau Salt\&Pepper (variance $=0,05$ ) dapat dilihat pada Tabel 4 . Tabel 4. Nilai PSNR Metode Bilateral Filter, Median Filter, dan Average Filter dari Citra yang Terdegradasi Derau Salt \& Pepper (variance $=0,05$ )

\begin{tabular}{|c|c|c|c|c|}
\hline \multicolumn{4}{|c|}{ Bilateral Filter } & \multirow[b]{2}{*}{$\begin{array}{c}\text { Rata-rata } \\
\text { tiap } \sigma_{S}\end{array}$} \\
\hline$\sigma_{R}$ & 0,05 & 0,5 & 5 & \\
\hline 0,5 & 32,80 & 34,32 & 34,88 & 34,00 \\
\hline 2 & 32,81 & 37,55 & 37,08 & 35,81 \\
\hline 20 & 32,83 & 35,23 & 34,46 & 34,17 \\
\hline Rata-rata $\sigma_{R}$ & 32,82 & 35,70 & 35,47 & \\
\hline \multicolumn{4}{|c|}{ Median Filter : $\mathbf{4 1 , 1 7}$} & \\
\hline \multicolumn{4}{|c|}{ Average Filter : 36,79} & \\
\hline
\end{tabular}

Berdasarkan Table 4, nilai PSNR tertinggi terdapat pada metode Median Filter yaitu sebesar 41,17. Sedangkan untuk metode Bilateral Filter terdapat pada kategori parameter sedang $\left(\sigma_{S}=2\right.$ dan $\left.\sigma_{R}=0,5\right)$ yaitu sebesar 37,55 dan Average Filter sebesar 36,79.

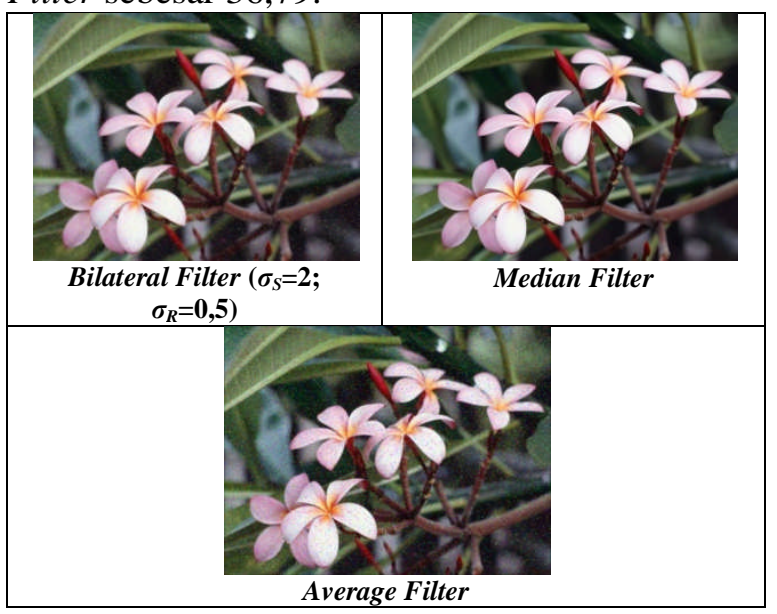

Gambar 5. Hasil penapisan derau Salt\&Pepper (variance $=0,05$ ) 


\subsection{Penapisan Derau Gaussian, Speckle dan Salt\&Peppe (variance $=0,5$ )}

a. Hasil penapisan derau Gaussian (variance $=$ $0,5)$ dapat dilihat pada Tabel 5.

Tabel 5. Nilai PSNR Metode Bilateral Filter, Median Filter, dan Average Filter dari Citra yang Terdegradasi Derau Gaussian (variance $=0,5$ )

\begin{tabular}{|c|c|c|c|c|}
\hline \multicolumn{4}{|c|}{ Bilateral Filter } & \multirow[b]{2}{*}{$\begin{array}{l}\text { Rata-rata } \\
\text { tiap } \sigma_{S}\end{array}$} \\
\hline$\sigma_{R}$ & 0,05 & 0,5 & 5 & \\
\hline 0,5 & 27,66 & 27,68 & 27,68 & 27,68 \\
\hline 2 & 27,67 & 27,69 & 27,69 & 27,68 \\
\hline 20 & 27,66 & 27,63 & 27,63 & 27,64 \\
\hline Rata-rata tiap $\sigma_{R}$ & 27,66 & 27,67 & 27,67 & \\
\hline \multicolumn{4}{|c|}{ Median Filter $: 27,67$} & \\
\hline \multicolumn{4}{|c|}{ Average Filter : 27,41} & \\
\hline
\end{tabular}

Berdasarkan Table 5, nilai PSNR tertinggi terdapat pada metode Bilateral Filter pada kategori parameter sedang $\left(\sigma_{S}=2\right.$ dan $\left.\sigma_{R}=0,5\right)$ yaitu sebesar 27,68. Sedangkan untuk Median Filter nilai PSNR sebesar 27,67 dan Average Filter sebesar 27,41. Pengaruh dari tingginya nilai variance noise pada derau Gaussian yang dikenakan pada citra menyebabkan warna pada citra hasil cenderung menjadi warna putih.

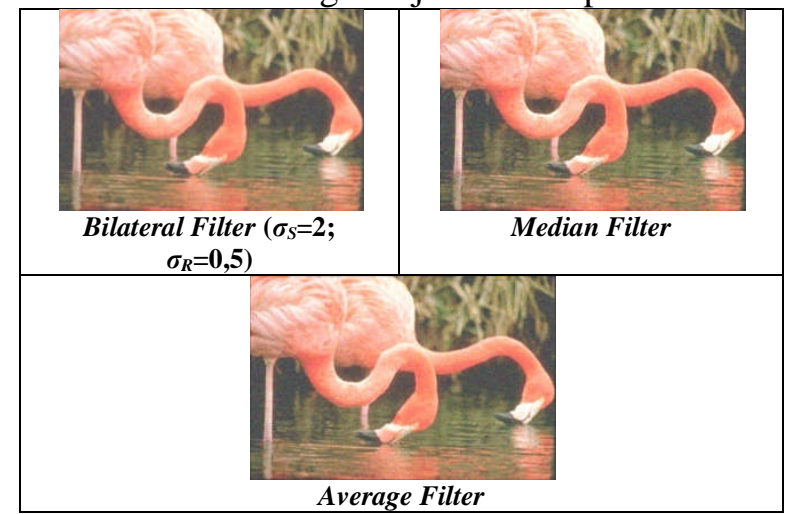

Gambar 6. Hasil penapisan derau Gaussian (variance $=0,5$ )

b. Hasil penapisan derau Speckle (variance $=$ 0,5) menggunakan metode Bilateral Filter, Median Filter, dan Average Filter dapat dilihat pada Tabel 6 .

Tabel 6. Nilai PSNR Metode Bilateral Filter, Median Filter, dan Average Filter dari Citra yang Terdegradasi Derau Speckle (variance $=0,5$ )

\begin{tabular}{|c|c|c|c|c|}
\hline \multicolumn{4}{|c|}{ Bilateral Filter } & \multirow[b]{2}{*}{$\begin{array}{c}\text { Rata-rata } \\
\text { tiap } \sigma_{S}\end{array}$} \\
\hline$\sigma_{R}$ & 0,05 & 0,5 & 5 & \\
\hline 0,5 & 30,45 & 31,67 & 32,55 & 31,56 \\
\hline 2 & 30,50 & 33,81 & 33,81 & 32,71 \\
\hline 20 & 30,62 & 33,56 & 33,87 & 32,69 \\
\hline Rata-rata $\sigma_{R}$ & 30,52 & 33,02 & 33,41 & \\
\hline \multicolumn{4}{|c|}{ Median Filter : 32,86} & \\
\hline \multicolumn{4}{|c|}{ Average Filter : $\mathbf{3 4 , 1 2}$} & \\
\hline
\end{tabular}

Berdasarkan Table 6, nilai PSNR tertinggi terdapat pada metode Average Filter yaitu sebesar 34,12. Sedangkan untuk metode Bilateral Filter terdapat pada kategori parameter tinggi $\left(\sigma_{S}\right.$ $=20$ dan $\sigma_{R}=5$ ) yaitu sebesar 33,81 dan untuk Median Filter sebesar 32,86.

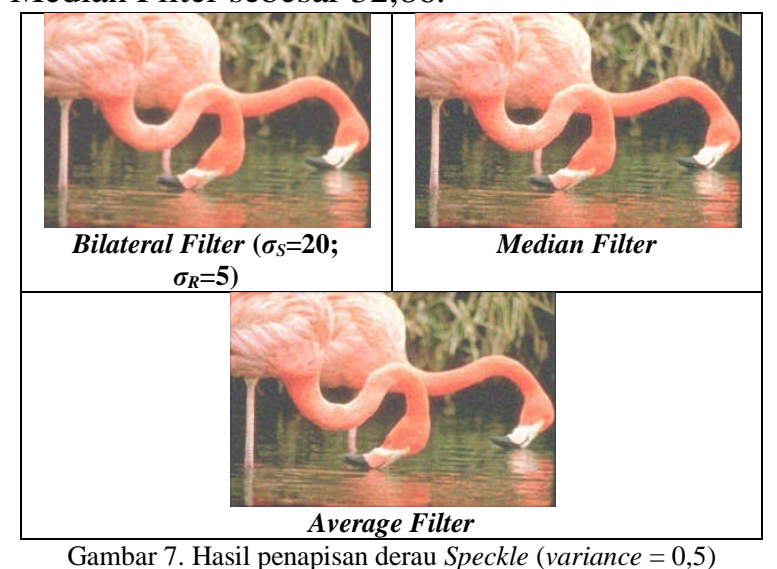

c. Hasil penapisan derau Salt\&Pepper (variance $=0,5)$ menggunakan metode Bilateral Filter, Median Filter, dan Average Filter dapat dilihat pada Tabel 7.

Tabel 7. Nilai PSNR Metode Bilateral Filter, Median Filter, dan Average Filter dari Citra yang Terdegradasi Derau Salt \& Pepper (variance $=0,5$ )

\begin{tabular}{|c|c|c|c|c|}
\hline \multicolumn{4}{|c|}{ Bilateral Filter } & \multirow[b]{2}{*}{$\begin{array}{c}\text { Rata-rata } \\
\text { tiap } \sigma_{S}\end{array}$} \\
\hline$\sigma_{R}$ & 0,05 & 0,5 & 5 & \\
\hline 0,5 & 27,83 & 28,82 & 29,43 & 28,70 \\
\hline 2 & 27,86 & 30,65 & 30,87 & 29,79 \\
\hline 20 & 27,91 & 30,81 & 30,78 & 29,83 \\
\hline Rata-rata $\sigma_{R}$ & 27,87 & 30,09 & 30,36 & \\
\hline \multicolumn{4}{|c|}{ Median Filter $: \mathbf{3 1 , 2 8}$} & \\
\hline \multicolumn{4}{|c|}{ Average Filter : 30,88} & \\
\hline
\end{tabular}

Berdasarkan Table 7, nilai PSNR tertinggi terdapat pada metode Median Filter yaitu sebesar 31,28. Sedangkan untuk metode Bilateral Filter terdapat pada kategori parameter sedang $\left(\sigma_{S}=2\right.$ dan $\sigma_{R}=5$ ) yaitu sebesar 30,87 dan untuk Average Filter sebesar 30,88.

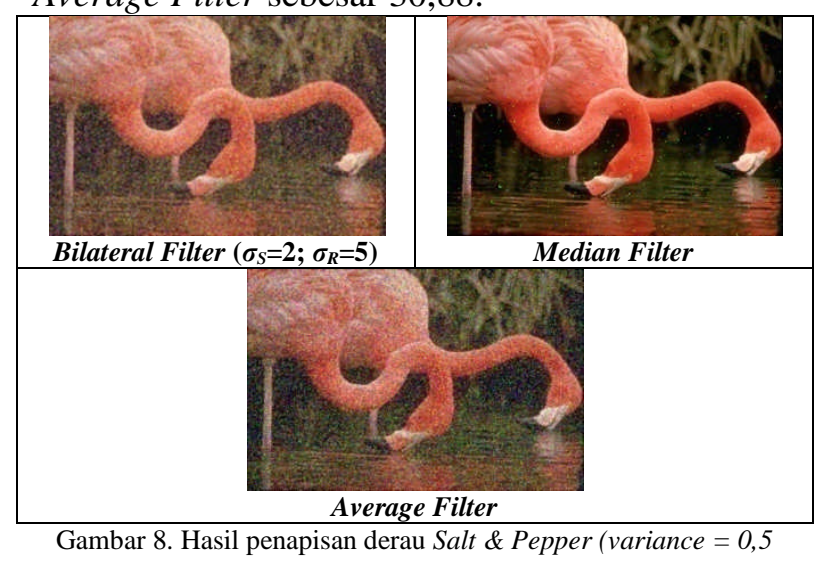




\section{KESIMPULAN}

Kombinasi parameter yang memberikan hasil terbaik dalam menapis derau Gaussian dan Speckle dengan nilai variance noise standar adalah metode Bilateral Filter kategori parameter sedang, yaitu $\sigma_{S}=2$ dan $\sigma_{R}=0.5$. Namun pada penapisan derau Salt \& Pepper, metode Median Filter memberikan hasil terbaik daripada kedua metode yang lain.

Nilai variance noise yang tinggi pada derau Gaussian mengakibatkan intensitas warna pada citra cenderung menjadi warna putih sehingga meskipun derau berhasil ditapis dari citra, kualitas citra yang dihasilkan tetap menurun karena warna citra memutih.

Nilai standar deviasi $(\sigma)$ yang terlalu kecil tidak memberikan pengaruh yang besar dalam proses penapisan derau. Tetapi, jika nilai standar deviasi terlalu besar, metode Bilateral Filter akan menapis derau dengan baik namun garis atau tepian objek pada citra ikut memudar.

\section{SARAN \\ Meningkatkan kecepatan proses pada implementasi metode Bilateral Filter, meningkatkan analisis terhadap metode Bilateral Filter dengan menggunakan parameter derau yang lebih bervariasi, dan menentukan parameter $\sigma_{S}$ dan $\sigma_{R}$ yang optimal.}

\section{UCAPAN TERIMA KASIH}

Terima kasih Penulis ucapkan kepada Universitas Haluoleo Fakultas Teknik Jurusan Teknik Informatika yang telah memberikan dukungan secara finansial sehingga penelitian dapat dilakukan. Terima kasih tidak lupa penulis ucapkan kepada FMIPA UGM yang telah memberikan bimbingan selama penelitian berlangsung hingga saat ini, serta kepada FST UIN SGD atas kerjasama dalam melakukan penelitian ini.

\section{DAFTAR PUSTAKA}

[1] Barash D. 2000. Bilateral Filtering and Anisotropic Diffusion: Towards an Unified Viewpoint. Israel : HP Laboratories Israel.

[2] Elad M. 2002. On The Origin of the Bilateral Filtering and Ways to Improve It. IEEE Transaction on Image Processing, Vol.II, No.10, Oktober 2002.

[3] Gonzalez R.C., Woods R.E., 2007, "Digital Image Processing”, New Jersey : Prentice-Hall,Inc.

[4] Jiang W, Baker ML, Qiu W, Bajaj C, Wah Chiu. 2003. Applications of Bilateral Denoising Filter in Biological Electron Microscopy. Journal of Structural Biology 144.

[5] Tomasi C, Manduchi R. 1998. Bilateral Filtering for Gray and Color Images. In Proceedings of the IEEE International Conference on Computer Vision, Bombay

[6] India.Jain A.K., 1989, "Fundamentals Of Digital Image Processing”, New Jersey : Prentice-Hall,Inc. 